\title{
MADRASAH
}

164

P a g e

Jurnal Pendidikan dan Pembelajaran Dasar

p ISSN: 1979-5599 | e ISSN: 2502-194X

\section{IMPLEMENTASI NILAI NILAI KARAKTER SISWA PADA PEMBELAJARAN PJOK DI MADRASAH IBTIDAIYAH}

\author{
Bintoro Widodo \\ Universitas Islam Negeri (UIN) Maulana Malik Ibrahim Malang, Indonesia \\ bennymalang@yahoo.com
}

\begin{abstract}
Pendidikan karakter adalah landasan awal untuk menciptakan generasi yang mempunyai moral ataupun akhlak yang mulia. Pendidikan karakter menjadi hal yang sangat diutamakan khususnya pada masa perkembangan anak sekolah. Pendidikan karakter membentuk siswa untuk mencontoh toladan yang baik dengan memahami figur Rasulullah SAW. Pendidikan Karakter dapat diterapkan melalui materi pembelajaran yang ada di sekolah, tidak terkecuali pelajaran PJOK. Pelajaran PJOK bisa menjadi bagian terpenting dalam pembentukan karakter dan perilaku anak. Melalui Pendidikan Jasmani siswa dikenalkan dengan pemahaman rasa tanggung jawab, sportifitas, jujur, adil dan penerapan nilai sosial. Hal ini menjadi penting dan perlu dilakukan oleh seorang pengajar Pendidikan jasmani di Sekolah khususnya di tingkat Madrasah Ibtidaiyah. Pendidikan Madrasah ibtidaiyah merupakan masa usia pembelajaran dasar yang bertujuan untuk membangun dasar karakter pada usai perkembangan anak untuk menuju masa perkembangan selanjutnya. Semakin baik guru membangunkarakter siswa maka akan memberikan manfaat berarti bagi perkembangan anak menghadapi perkembangan usia dewasa.
\end{abstract}

Keyword: Nilai-nilai Karakter; Teladan; Pembelajaran PJOK

Copyright (C) 2017 Madrasah Jurnal Pendidikan dan Pembelajaran Dasar. All Right Reserved

\section{A. PENDAHULUAN}

Pendidikan mempunyai peran yang besar dalam pembentukan karakter bangsa Indonesia. Pendidikan tidak hanya mentransformasikan pengetahuan saja, tetapi juga mempunyai peran dalam membentuk karakter bangsa. Dengan kata lain pendidikan hendaknya membentuk insan yang cerdas dan berkarakter, sehingga akan menciptakan bangsa yang unggul dalam prestasi dan santun berinteraksi sesuai dengan nilai-nilai luhur bangsa. Hal ini juga dipertegas oleh Bung Karno Muchlas Samani dan Hariyanto yang menyatakan bahwa Bangsa ini harus dibangun dengan mendahulukan pembangunan karakter (character buliding) karena character building inilah yang akan membuat Indonesia menjadi bangsa yang besar, maju dan jaya serta bermartabat. Kalau character building ini tidak dilakukan, maka bangsa Indonesia akan menjadi bangsa kuli.

George F. Kneller mengemukakan pendapatnya bahwa dalam arti luas pendidikan menunjuk pada 2 suatu tindakan atau pengalaman yang mempunyai pengaruh yang berhubungan dengan pertumbuhan atau perkembanganjiwa (mind), watak (character), atau kemampuan fisik (physical abilty) individu. Pendidikan juga merupakan suatu bentuk wujud nyata akan usaha manusia menjadi makhluk yang beradab. John S. Brubacher menegaskan bahwa pendidikan merupakan proses dalam mana potensi-potensi, kemampuan-kemampuan, kapasitas-kapasitas manusia yang mudah dipengaruhi oleh

Vol. 9 No. 2, Juni 2017

Madrasah homepage: http://ejournal.uin-malang.ac.id/index.php/madrasah/index 
kebiasaan-kebiasaan, disempurnakan dengan kebiasaan-kebiasaan yang baik, dengan alat (media) yang disusun sedemikian rupa, dan digunakan oleh manusia untuk menolong orang lain atau dirinya sendiri dalam pencapaian tujuan-tujuan yang ditetapkan. Kemajuan zaman dengan arus globalnya tersebut tidak mungkin bisa sampai menimbulkan bahaya yang akhirnya merusak kehidupan bangsa jika dari dalam diri generasi kita sudah tertanam iman yang kuat, iman yang menolak akan segala sesuatu yang bertentangan dengan keinginan dari dalam hatinya.

Karakter yang sudah mengkristal inilah yang menjadi benteng bagi fikiran dan hati sehingga tidak mudah dikendalikan oleh nafsu yang hanya mementingkan kesenangan di dunia dan mengabaikan pertanggungajawaban di akhirat. Inilah yang membuat MI KH. A. Thohir bersikeras dalam mengupayakan pembentukan karakter anak didiknya, meskipun dalam penanaman karakter pada siswa masih belum berjalan dengan lancar, kemudian besarnya peran pendidikan karakter dalam proses pendidikan yaitu untuk membentuk butiran kristal supaya bisa tertanam dalam diri setiap generasi muda. Pembentukan karakter dalam diri tersebut harus ditanamkan sejak masih usia anak yaitu masa emas dimana pembentukan kepribadian sangat diperlukan, karena jika nilai-nilai luhur sudah terbentuk dalam diri anak sejak dini maka ketika dewasa ia akan menjadi manusia yang bertanggungjawab dan bermartabat.

Dalam Islam pendidikan karakter menjadi hal yang sangat diutamakan. Sebagaimana sabda Rasululllah SAW, yang artinya "sesungguhnya orang pilihan di antara kamu ialah orang yang baik akhlaknya." Pendidikan karakter dengan memberikan teladan yang baik dengan figur Rasulullah SAW sebagai panutan adalah suatu hal yang sangat dianjurkan bahkan di haruskan dalam Islam. Oleh karenanya jika anak sejak kecil sudah dibiasakan untuk mengenal karakter positif sesuai tauladan yang diajarkan Rasulullah maka ketika dewasa ia akan tumbuh menjadi generasi yang tangguh, percaya diri dan berkarakter kuat. Untuk itu sekolah perlu menyadari keberadaan berbagai macam budaya sekolah dengan sifat yang positif dan negatif dimana nilai-nilai dan keyakinan tidak akan hadir dalam waktu singkat. Budaya sekolah perlu melandasi dan memiliki tujuan dalam membangun karakter siswa dan mempersiapkan siswa mencapai keberhasilan akademis. Untuk itu Madrasah sebagai salah satu bagian proses pendidikan anak di usia dini merupakan sarana pembelajaran bagi penciptaan karakter anak, melalui berbagai mata pelajaran yang diajarkan.

\section{B. PEMBAHASAN}

Pengertian pendidikan karakter itu sendiri adalah suatu sistem penanaman nilainilai karakter kepada warga sekolah yang meiiputi komponen pengetahuan, kesadaran kemauan, dan tindakan untuk melaksanakan nilai-nilai tersebut, baik terhadap Tuhan Yang Maha Esa, diri sendiri, sesama, lingkungan, rnaupun kebangsaan sehingga menjadi manusia beradab dan berbudaya. Pendidikan karakter adalah pendidikan budi pekerti plus, yang melibatkan aspek pengetahuan (cognitive), perasaan (feeling), dan tindakan (action). Menurut Thomas Lickona, tanpa ketiga aspek ini, maka pendidikan karakter tidak akan efektif dan pelaksanaannya pun harus dilakukan secara sistematis dan berkelanjutan. Dengan pendidikan karakter, seorang anak akan menjadi cerdas emosinya. Kecerdasan emosi adalah bekal penting dalam mempersiapkan anak menyongsong masa depan. Dengan kecerdasan emosi, seseorang akan dapat berhasil dalam menghadapi segala macam tantangan, termasuk tantangan untuk berhasil secara akademis.

Vol. 9 No. 2, Juni 2017

Madrasah homepage: http://ejournal.uin-malang.ac.id/index.php/madrasah/index 


\section{MADRASAH}

Dalam buku Emotional Intelligence and School Succes mengkomplikasikan berbagai hasil penelitian tentang pengaruh kecerdasan emosi anak terhadap keberhasilan di sekolah. Dikatakan bahwa ada berbagai faktor-faktor resiko penyebab kegagalan anak di sekolah. Faktor-faktor resiko yang disebutkan temyata bukan terletak pada kecerdasan otak, tetapi pada karakter, yaitu rasa percaya diri, kemampuan bekerja sama, kemampuan bergaul, kemampuan berkonsentrasi, rasa empati, dan kemampuan berkomunikasi. Hal ini sesuai dengan pendapat Daniel Goleman tentang keberhasilan seseorang di masyarakat, ternyata $80 \%$ dipengaruhi oleh kecerdasan emosi, dan hanya 20\% ditentukan oleh kecerdasan otak (IQ). Dalam hal pendidikan karakter, Ary Ginajar Agustian adalah pribadi yang sangat peduli terhadap pembentukan karakter bangsa Indonesia, dengan landasan teoretis dan pengembangan model yang dirancang secara matang. Hal ini dijelaskan dalam model Emotional Spiritual Quetient (ESQ), yaitu sinergi antara kecerdasan spiritual sebagai basss nilai utama, kecerdasan emosional sebagai landasan mental, dan kecerdasan intelektual sebagai solusi hal-hal teknis, Model ESQ adalah mekanisme mengelola kecerdasan intelektual, emosional, dan spiritual.

M Zainuddin dalam bukunya menyebutkan bahwa, empat belas abad yang lalu, Nabi Muharnmad SAW mengingatkan tentang: "Sesungguhnya dalarn tubuh terdapat segumpal darah. Jika ia baik, maka baik pula tubuh itu, Jika ia rusak, maka rusak pulalah tubuh itu. segumpal darah itu adalah hati". Dapat dipahami bahwa pendidikan karekter dalam Islam sejak zaman dahulu sudah ada. Pendidikan karakter yang diintegrasikan dalam pembelajaran berbagai bidang studi dapat memberikan pengalaman yang bermakna bagi murid-murid karena mereka memahami, menginternalisasi, dan mengaktualisasikannya melalui proses pembelajaran. Dengan demikian, nilai-nilai tersebut dapat terserap secara alami melalui kegiatan sehari-hari. Dalam perkembangan pola intraksi dan komunikasi dunia yang begitu pesat, dewasa ini kedudukan olahraga tidak dapat dipandang sebagai bagian suplemen dari tata kehidupan manusia. Olahraga termasuk pendidikan yang sarat dengan muatan berbagai nilai yang kini menjadi bagian integral dari sisi kehidupan manusia.

Dewasa ini nilai-nilai dalam olahraga dan pendidikan jasmani telah mengalami metmorfase sesuai dengan situasi dan kondisi yang terjadi disekelilingnya. Olahraga tidak dipandang sebagai selingan untuk mengisi waktu luang, melainkan sebagai kegiatan yang intergal dari sisi kehidupan sehari-hari yang mempunyai hubungan dengan aspek psikososial. Aktivitas jasmani dan olahraga memberikan kesempatan untuk terikat dan terhubung dengan orang lain. Temuan menunjukkan bahwa partisipasi dalam aktivitas jasmani memupuk rasa keterbukaan antar pribadi ketimbang rasa terisolasi. Keterlibatan dalam aktivitas jasmani akan memberi individu perasaan memiliki, rasa kebersamaan dan membuat mereka merasa menjadi salah satu anggota dari kelompok. Selain itu aktivitas jasmani dan olahraga juga memberi kesempatan pada individu untuk meningkatkan keterampilan sosial dan memperluas pengalaman sosial. Beberapa orang menyatakan bahwa dengan partisipasi dalam aktivitas jasmani membuka kesempatan untuk mempelajari keterampilan interpersonal penting yang mampu meningkatkan intraksi sosial mereka.

Olahraga dan aktivitas jasmani membantu seseorang untuk belajar kerjasama, memberikan kesempatan untuk belajar tentang orang lain, dan mengajarkan satu cara untuk mengukur orang lain. Selain itu sering disebutkan bahwa dengan berpartisipasi membantu mereka untuk berhadapan dengan situasi soaial di luar konteks aktivitas

Vol. 9 No. 2, Juni 2017

Madrasah homepage: http://ejournal.uin-malang.ac.id/index.php/madrasah/index 
jasmani. Dengan aktif dalam olahraga dan aktifitas jasmani seseorang memperoleh rasa kerja tim dan kepemimpinan. Kepemimpinan dan kerjasama tim dapat membantu mislanya saat berada dalam dunia bisnis, ketika individu harus bekerja dengan orang lain atau bekerja dalam kelompok untuk menyelesaikan tugas. Sebuah aspek penting dalam aktifitas jasmani adalah untuk membantu anak untuk bersosialisasi antar individu. Sebuah program kegiatan fisik menawarkan kesempatan tak terbatas untuk mengembangkan pemahaman sosial yang luas, kontak awal antara budaya masyarakat yang sebelumnya jauh dapat dilakukan melalui kepentingan bersama dalam olahraga. Efek dari aktifitas jasmani dan nilai-nilai yang terdapat didalamnya apakah itu aktivitas jasmani yang dilakukan perorangan, berpasangan dan kelompok akan sangat berpengaruh dalam kehidupan anak dimasa sekarang dan masa yang akan datang.

Aktivitas jasmani berhubungan dengan pengalaman sosial, kesehatan dan kebuguran jasmani, pengalaman yang berhubungan dengan nilai estetika dan berhubungan dengan karakter seseorang. Kebutuhan untuk bergaul dengan penuh kehangatan dan persahabatan merupakan kebutuhan yang asasi dari setiap manusia. Oleh karena itu diperlukan media yang dapat mengakomodasi berbagai kebutuhan manusia. Olahraga dan pendidikan jasmani dengan karakter nilai sosialnya terbuka dapat dimasuki manusia dari berbagai kelompok sosial, misalnya melalui aktivitas permainan seperti permainan bola basket, cenderung menciptakan hubungan sosial antar pemain sehingga aktifitas tersebut berdampak pada aspek psikososial. Sebagai kelanjutan dari perkembangan tahap selanjutnya, pada masa ini anak sangat aktif mempelajari apa saja yang ada dilingkungannya.

Dorongan untuk mengetahui dan berbuat terhadap lingkungannya sangat besar, tetapi dipihak lain karena keterbatasan-keterbatasan kemampuan dan pengetahuannya kadang-kadang dia menghadapi kesukaran, hambatan bahkan kegagalan. Dalam masa anak-anak ini melalui teman sebayanya, anak menumbuhkan kepercayaan diri pada kemampuannya dan berlatih menggunakan kemampuan imajinasinya. Dengan pengaruh teman-teman sebayanya pula anak mengembangkan kemampuan kognitifnya termasuk juga dengan kemampuan berkomunikasi, bekerjasama, memimpin dan menjalankan perannya. Pada usia ini anak akan mengembangkan nilai-nilai, mengeluarkan energi, mengeksplorasi batas-batas, bernegoisasi, dan belajar untuk merasa memiliki dengan bantuan teman sebayanya. Pada hakekatnya pembelajaran yang berlandaskan nilai-nilai karakter selalu memperhatikan beberapa aspek pendukung dalam pembelajaran yang berintraksi pada nilai-nilai karakter, seperti:

1. Metode-metode pembelajaran dapat diartikan sebagai perencanaan yang berisi tentang rangkaian kegiatan yang didesain untuk mencapai tujuan pendidikan tertentu yang disini pendidikan bertujuan untuk membentuk kepribadian siswa. Kemudian dilanjutkan dengan upaya mengimplementasikan rencana yang sudah disusun dalam kegiatan nyata agar tujuan yang telah disusun tercapai secara optimal. Seorang guru harus mampu memahami secara baik tentang peran dan fungsi metode dalam proses pembelajaran, misalnya metode ceramah, diskusi, tanya jawab, demonstrasi dan sebagainya.

2. Media. Dalam buku Setrategi Pembelajaran Berorientasi Pada Standar Proses Pendidikan yang ditulis oleh Wina Sanjaya mengemukakan bahwa media pembelajaran adalah alat dan bahan yang dapat dipakai untuk mencapai tujuan pendidikan seperti karya sastra, radio, televisi, buku, koran, majalah dan lain sebagainya. Namun demikian media bukan hanya alat-alat dan bahan yang mahal saja tetapi barang yang kurang berharga

Vol. 9 No. 2, Juni 2017

Madrasah homepage: http://ejournal.uin-malang.ac.id/index.php/madrasah/index 


\section{MADRASAH}

sekalipun bisa dijadikan media pembelajaran dalam kelas. Hal itulah yang saat ini sedang digalakkan oleh setiap lembaga pendidikan karena di samping murah, media ini juga lebih memancing munculnya kreativitas dari para peserta didik.

\section{SIMPULAN}

Karakter adalah watak, tabiat, akhlak, atau kepribadian seseorang yang terbentuk dari hasil internalisasi berbagai kebajikan (virtues) yang diyakini dan digunakan sebagai landasan untuk cara pandang, berpikir, bersikap, dan bertindak. Kebajikan terdiri atas sejumlah nilai, moral, dan norma, seperti jujur, berani bertindak. dapat dipercaya. dan hormat kepada orang lain. Interaksi seseorang dengan orang lain menumbuhkan karakter masyarakat dan karakter bangsa. Oleh karena itu, pengembangan karakter bangsa hanya dapat dilakukan melalui pengembangan karakter individu seseorang, dalam pernbahasan ini adalah siswa.

Akan tetapi, karena manusia hidup dalam lingkungan sosial dan budaya tertentu, maka pengembangan karakter individu seseorang hanya dapat dilakukan dalam lingkungan sosial dan budaya yang bersangkutan Artinya, pengembangan budaya dan karakter bangsa hanya dapat dilakukan dalam suatu proses pendidikan yang tidak melepaskan peserta didik dari lingkungan sosial, budaya masyarakat, dan budaya bangsa. Lingkungan sosial dan budaya bangsa adalah Pancasila, jadi pendidikan budaya dan karakter bangsa haruslah berdasarkan nilai-nilai Pancasila.

Dipembelajaran PJOK nilai-nilai yang terkandung sebagaimana untuk membangun karakter siswa dapat tertuangkan dalam aktifitas olahraga. Kedisiplinan, tanggung jawab. hormat menghormati serta kejujuran. Semua itu dapat diaplikasikan melalui kegiatan olahraga. Pendidikan karakter yang tercipta dari pembelajaran PJOK dapat melalui kegiatan permainan dengan melibatkan permainan individu dan permainan kelompok. Bagaimana seorang guru penjas dapta memberikan aplikasi nilai-nilai pendidikan karakter pada pembelajaran PJOK pada siswa Madrasah yang tidak lepas dari kaidah norma agama, masyarakat dan bangsa.

\section{REFERENSI}

Muchlas Samani \& Hariyanto. (2011). Konsep dan Model Pendidikan Karakter. Bandung: PT. Remaja Rosdakarya.

Dwi Siswoyo, dkk. (2008). Ilmu Pendidikan. Yogyakarta: UNY Press.

Maftuh Ahnan Asy, Kumpulan Hadits Terpilih Shohih Bukhari, (Surabaya: Terbit Terang, tanpa tahun terbit).

Darmiyati Zuchdi, Zuhdan Kun Prasetya, dan Muhasinatun Siasah Masruri, Pengembangan Model Pendidikan Karakter Terintgrasi dalam Pembelajaran Bidang Studi di Sekolah Dasar Jurnal Cakrawala Pendidikan, Mei 2010, Th, XXIX, Edisi Khusus Dies Natalis UNY

Zainuddin, M. (2008). Paradigma Pendidikan Terpadu Menyiapkan Generasi Ulul Albab. Malang: UIN Malang Press.

http:/ / saifuladi.wordpress.com/2007/11/19/fungsi-guru-siswa-sudah-berubah/, diakses pada hari sabtu, tanggal 12 Mei 2012 pukul 15.00 WIB)

Wina Sanjaya. (2007). Strategi Pembelajaran Berorientasi pada Standar Proses Pendidikan. (Jakarta: Kencana.

Vol. 9 No. 2, Juni 2017

Madrasah homepage: http://ejournal.uin-malang.ac.id/index.php/madrasah/index 